\title{
Komunikasi Adaptasi Lintas Budaya Pencari Suaka dalam Berinteraksi dengan Masyarakat Kota Pekanbaru
}

\author{
Ringgo Eldapi Yozani \\ Fakultas Ilmu Sosial dan Ilmu Politik Universitas Riau, Indonesia
}

\begin{abstract}
ABSTRAK
Banyak cara yang dilakukan manusia dalam beradaptasi dengan lingkungannya yang baru. Salah satunya dengan mengikuti alur dan suasana di lingkungan baru tersebut. Adaptasi dalam konteks komunikasi lintas budaya berkaitan erat dengan adapatasi budaya dan adaptasi sosial. Pencari suaka merupakan pendatang baru yang dalam hal ini sebagai orang yang memiliki budaya minoritas dimana mereka dituntut harus mampu beradaptasi agar mereka dapat mempertahankan kehidupan dan dapat berkembang dengan baik di tempat yang memiliki budaya yang mayoritas. Penelitian ini bertujuan untuk megetahui bagaimana proses komunikasi adaptasi lintas budaya yang dilakukan oleh pencari suaka dalam berinteraksi dengan sasyarakat Kota Pekanbaru. Penelitian ini menggunakan Teori Interaksi Simbolik, Teori Akomodasi Komunikasi, serta Teori Adaptasi Lintas Budaya. Metode yang digunakan dalam penelitian ini adalah metode penelitian Kualitatif dengan Pendekatan Fenomenologi Alfred Schutz. Pengumpulan data dilakukan dengan wawancara mendalam terhadap para pencari suaka, observasi, serta studi dokumentasi dari para pencari suaka dalam beraktivitas sehari-hari. Hasil dari penelitin ini adalah komunikasi adaptasi lintas budaya yang dilakukan oleh pencari suaka dilakukan melalui dua strategi, yakni strategi konvergensi dan strategi divergensi. Strategi Konvergensi dilakukan dengan komunikasi verbal, komunikasi nonverbal, adaptasi berdasarkan kesamaan agama, cara berpakaian, serta beradaptasi denga iklim di Kota Pekanbaru. Startegi divergensi yang dilakukan oleh pencari suaka secara verbal ketika berada di dalam grup mereka lebih cenderung menggunakan bahasa daerah mereka meskipun kondisinya pada saat itu mereka berada di tengah masyarakat Kota Pekanbaru. Para pencari suaka tidak menghiraukan jarak saat berkomunikasi dan tidak berusaha mengetahui kebutuhan jarak lawan bicaranya dan berusaha mengetahui apakah jarak tersebut membuat nyaman lawan bicaranya disebabkan mereka berinteraksi dengan masyarakat pribumi jika hanya untuk memenuhi keperluannya saja.
\end{abstract}

\begin{abstract}
Many ways that humans do in adapting to their new environment. One of them by following the flow and atmosphere in the new environment. Adaptation in the context of cross-cultural communication is closely related to cultural adaptation and social adaptation. Asylum seekers are newcomers in this case as people who have a minority culture where they are required to be able to adapt so they can maintain life and can thrive in a place that has a majority culture. This study aims to find out how the cross-cultural adaptation communication process by asylum seekers in interacting with the people of Pekanbaru City. This research uses the Symbolic Interaction Theory, Communication Accommodation Theory, and CrossCultural Adaptation Theory. The method used in this study is a qualitative research
\end{abstract}

KATA KUNCI Komunikasi Adaptasi Lintas Budaya; Pencari Suaka; Adaptasi; Konvergensi; Divergensi

KEYWORDS

Cross-Cultural Adaptation Communication; Asylum Seeker; Adaptation; Convergence; Divergence 
method with the Alfred Schutz Phenomenology Approach. Data collection is done by in-depth interviews with asylum seekers, observation, and documentation studies from asylum seekers in their daily activities. The results of this research are crosscultural adaptation communication carried out by asylum seekers through two strategies, namely the convergence strategy and the divergence strategy. The Convergence Strategy is carried out with verbal communication, nonverbal communication, adaptation based on religious similarity, how to dress, and to adapt to the climate in Pekanbaru City. The divergence strategy practiced by asylum seekers verbally when in their groups is more likely to use their local language even though the conditions at that time were in the midst of the people of Pekanbaru City. Asylum seekers do not pay attention to distance when communicating and do not try to find out the distance needs of their interlocutors and try to find out whether the distance makes them comfortable because they interact with the indigenous community if only to fulfill their needs.

\section{PENDAHULUAN}

Provinsi Riau merupakan salah satu provinsi yang dilalui oleh para pencari suaka sebelum mereka sampai di Negara tujuan akhirnya. Di Provinsi Riau, khususnya Kota Pekanbaru banyak dijadikan sebagai tempat transit bagi para pencari suaka, dikarenakan kondisi geografis Provinis Riau dan Kota Pekanbaru yang sangat strategis yang langsung berhadapan dengan Malaysia. Kementrian Hukum dan Hak Asasi Manusia merupakan ujung tombak dari penangan permasalahan pencari suaka ini. Lembaga keimigrasian mempunyai peranan dalam pengawasan perpindahan orang dari negara asalnya ke negara kenegara baru yang akan menjadi tujuan dari para pencari suaka tersebut. Meskipun telah dilakukan pengawasan yang cukup maksimal, akan tetapi pihak keiimgrasian masih sering luput dalam melakukan kegiatan pengawasan tersebut. Hal ini terbukti dengan banyak masuknya para pencari suaka ke Indonesia tanpa disertai dengan dikumen-dokumen resemi seperti pasport dan visa. Ketika ditemukannya warga negara asing yang memasuki wilayah Indonesia tanpa disertai dengan dokumendokumen resmi kenegaraan, maka warga negara asing tersebut diproses sehingga ditetapkan menjadi sebagai seorang pencari suaka dan nantinya ditempatkan di Rumah Detensi Imigrasi (Rudenim).

Rudenim di kota Pekanbaru ini juga terdapat keunikan tersendiri yang berbeda dari rudenim-rudenim lain yang tersebar di kota-kota Indonesia. Rudenim di kota Pekanbaru adalah salah satu rudenim yang memperbolehkan para pencari suaka keluar masuk rudenim dan bebas beraktifitas diluar rudenim. Menurut informasi yang didapat dari kepala bidang keamanan bahwasanya rudenim membuat aturan dan tata tertib bagi pencari suaka yang ingin keluar-masuk dari rudenim. Para pencari suaka diizinkan keluar untuk membeli kebutuhan mereka, seperti kebutuhan perlengkapan mandi dan lain-lain. Adapun peraturannya yang diberlakukan oleh Rudenim adalah memperbolehkan pencari suaka keluar maksimal 3,5 jam, dimulai dari pukul 08:00 WIB 
hingga pukul 18:00 WIB. Jika lewat dari waktu yang ditentukan maka pencari suaka yang melanggar akan dikenakan sanksi. Sanksi yang diberikan berupa pengurungan di dalam sel selama 7 hari, para pencari suaka tidak diperbolehkan keluar selama 7 hari dan kartu tanda pengenal akan ditahan. Jam keluar dilakukan dengan sistem genap ganjil tergantung nomor dari registasi peserta. Para pencari suaka yang memiliki nomor urut registrasi ganjil akan diberikan waktu keluar pada tanggal ganjil, begitu juga dengan nomor urut registrasi genap akan diberikan waktu keluar pada tanggal genap pula. Berikut kutipan wawancara penulis dengan kepala subseksi ketertiban Rudenim Pekanbaru:

"Rudenim Pekanbaru memiliki Tata tertib sendiri yang mengatur pencari suaka untuk keluar dari Rudenim. Kita membuat aturan ini bukan tanpa sebab. Pertama, mereka bukan sebagai penjahat yang melakukan tindakan kriminal, kedua mereka adalah manusia biasa yang ingin juga bersosialisasi dan berinteraksi. Kalau mereka ingin kabur juga tidak bisa, karena mereka tidak memiliki dokumen resmi seperti Pasport dan Visa. Peraturan ini kita buat juga dengan aturan-aturan yang disepakati. Seperti satu hari hanya diperbolehkan keluar selama 3,5 jam dari jam 08.00 WIB - 18.00 WIB. Selanjutnya diberlakukan sistem ganjil genap sesuai dengan nomor registrasi mereka pencari suaka, yang registrasi ganjil bisa keluar di tanggal ganjil, dan begitu juga dengan genap. Radius yang kita perbolehkan juga maksimal 10 KM dari Rudenim" (Wawancara dengan subseksi ketertiban Rudenim Pekanbaru).

Dengan diberlakukannya Standar Operasional Prosedur (SOP) diatas oleh pihak Rudenim Kota Pekanbaru, membuat peluang yang sangat besar untuk terjadinya interaksi antara Pencari suaka dengan masyarakat di sekitar Rudenim di Kota Pekanbaru. Dari hasil pengamatan sementara yang peneliti lakukan, banyak para pencari suaka yang beraktifitas di luar Rudenim seperti masyarakat Kota Pekanbaru pada umumnya. Pada sore hari para pencari suaka bebas beraktifitas seperti berolahraga dan melakukan kegiatan lainnya dibekas kawasan Musabaqoh Tilawatil Qur'an (MTQ) dan di pusat kebugaran (Fitness Center) yang ada di Pekanbaru.

Dalam memenuhi kebutuhan hidupnya, membuat pencari suaka agar berinteraksi dengan masyarakat demi memenuhi kebutuhan mereka sehari-hari. Para pencari suaka dituntut harus bisa menyesuaikan diri dengan lingkungan barunya. Setiap pencari suaka harus mampu beradaptasi dengan masyarakat Kota Pekanbaru. Melalui proses adaptasi yang dilakukan melalu komunikasi lintas budaya, pencari suaka bias menyesuaikan diri dan berhubungan dengan serta mendapatkan rasa memiliki dalam masuk kedalam kelompok masyarakat Kota Pekanbaru. Para pencari suaka ketika berkomunikasi dengan orang-orang disekitarnya yang meliputi respect, empathy, audible, clarity, humble, adaptability, acceptance, cultural awareness, dan knowledge discovery; intensitas komunikasi, dan kompetensi komunikasi transbudaya yang dimiliki oleh tiap imigran Timur Tengah juga ikut andil dalam memperlancar komunikasi antarbudaya. Proses komunikasi lintas budaya tidak akan terlepas dari berbagai faktor pendukung, seperti persepsi proses komunikasi verba dan nonverbal serta konteks dalam berkomunikasi. 
Adaptasi merupakan kemampuan, ketrampilan individu dan kelompok sosial dalam menghadapi lingkungan serta menghadapi perubahan-perubahan yang terjadi di dalam lingkungan hidupnya (Bennet, 2005). Bennet juga mengatakan setiap manusia akan berusaha untuk menyesuaikan diri dengan lingkungan baru disekitarnya, baik secara biologis atau genetic serta secara kebudayaan. Hal tersebut merupakan proses adaptasi dalam evolusi ayng melibatkan genetic serta varian budaya sebagai cara yang terbaik dalam melakukan penyesuaian dengan lingkungannya (Bennet, 2005). Berbagai cara dilakukan oleh manusia untuk dapat menyesuaiakan diri dengan lingkungan barunya. Salah satunya dengan mengikuti alur dan suasana di lingkungan baru itu. Ada kalanya manusia merubah kepribadian aslinya untuk menyesuaikan diri dengan lingkungan itu. Adaptasi diri yang dilakukan melalui mekanisme penyesuaian diri tergantung dari individu yang bersangkutan, dimana individu dapat mengubah diri sesuai dengan keadaan lingkungan, tetapi dapat juga individu mengubah lingkungan sesuai dengan keadaan dan keinginan dirinya sendiri. Jadi adaptasi sangat bergantung pada individu dalam melihat hambatan dan kesulitan yang dialami ketika melakukan interaksi dengan lingkungan barunya.

Penulis mengutip penelitian terdahulu dari Yoki Yusanto yang meneliti tentang Komunikasi lintas budaya orang Asli Papua (OAP) di Belanda. Pada penelitian ini Yoki mengungkapkan Motif Berkomunikasi Orang Asli Papua (OAP) di Belanda pada Konteks Identitas dan Bagaimana Orang Asli Papua (OAP) di Belanda dalam memaknai Papua (Yusanto, 2018). Selanjutnya penelitian yang dilakukan Rd. Nia Kania dengan Judul Komunikasi Lintas Budaya Diaspora Indonesia di Jerman Hasil penelitian Nia Kania menunjukan bahwa Diaspora Indonesia berorientasi dan mengkoordinasikan perilaku mereka dalam rangka mencapai fungsi social; memperoleh tujuan pribadi, dan yang sesuai dengan situasi dan harapan normative (Kurniawati, 2016).

Penelitian selanjutnya yang dilakukan Lubis dengan judul Komunikasi Antar budaya Etnis Tionghoa dan Pribumi di Kota Medan. Tujuan penelitian ini untuk mengetahui komunikasi antar budaya mepengaruhi pandangan dunia etnis Tionghoa dan pribumi di Kota Medan (Lubis, 2012). Terakhir riset yang dilakukan Anne McNevin, Antje Missbach, dan Deddy Mulyana yang dimuat dalam Jurnal International Political Sosiology pada tahun 2016 dengan judul "The Rasionalities of Migration Management: Control and Subversion in an Indonesia-Based Counter-Smuggling Campaign". Artikel ini membahas tentang sebuah kampanye kontra-penyelundupan yang didanai oleh Australia dan dikirim di Indonesia dari tahun 2009 sampai 2014 sebagai sebuah contoh terhadap rezim peraturan global yang dikenal sebagai Manajemen Migrasi (McNevin, Missbach, \& Mulyana, 2016).

Di seluruh dunia, jutaan orang melakukan perpindahan lokasi dan melintasi budaya dan subbudaya tiap tahunnya, walaupun kejadian unik ini terjadi semua orang asng dalam lingkungan yang tidak familiar akan membina dan menjaga hubungan yang relatif stabil 
dan resiprokal dengan lingkungan asingnya. Young Yun Kim (Littlejohn \& Foss, 2009) memberikan penjelasan ini dengan teori adaptasi lintas budaya (Cross-culture adaptation Theory). Kerangka kerja teori ini terbagi atas tiga kondisi, yaitu: (1). Orangorang asing memiliki sosialisasi primer dalam satu budaya dan sub budaya dan dapat berpindah ke budaya atau sub budaya lain yang berbeda atau tidak dikenal. (2). Mereka setidaknya memiliki ketergantungan dengan lingkungan tuan rumah untuk kebutuhan personal dan social. (3). Mereka secara regular terlibat komunikasi awal dengan lingkungan tersebut. Kim (2001) menenyatakan bahwa adaptasi budaya merupakan proses yang sangat panjang untuk melakukan penyesuaian dan untuk akhirnya dapat merasakan kenyamanan di dalam lingkungan yang baru (Martin, Nakayama, \& K, 2012). Bahwa adaptasi ini suatu proses dari rasa stres (stress), penyesuaian (adjustment), dan perkembangan (growth). Ketika seseorang meraskan stress dikarenakan tidak cocok dengan lingkungannya, respon alami selanjutnya adalah mencari penyesuaian. Proses penyesuaian ini memunculkan kejatuhan mental seseorang akan sikap dan perilaku yang pernah dipegang sebelumnya, adapatasi ini terjadi diakibatkan oleh komunikasi, sehingga ketika mereka berkomunikasi dengan komunikan di lingkungan barunya, secara perlahan-lahan akan muncul jalan pemikiran dan perilaku yang baru. Dan selama itu orang tersebut akan mencapai level baru dari fungsi budaya yang inilah dinamakan identitas lintas budaya.

Komunikasi adaptasi lintas budaya para pencari suaka dalam berinteraksi dengan masyarakat Kota Pekanbaru dirasa memiliki nilai kebaruan diantara riset-riset sejenis terdahulunya. Hal ini dikarenakan fenomena yang terjadi di Kota Pekanbaru yakni dengan adanya peraturan yang memperbolehkan para pencari suaka keluar rudenim, sehingga membuat peluang untuk terjadi interaksi yang lama kelamaan nantinya para pencari suaka tersebut berpotensi untuk melakukan adaptasi. Adaptasi dalam konteks komunikasi lintas budaya berkaitan erat dengan adapatasi budaya dan adaptasi sosial. Orang-orang asing yang akan menetap dalam jangka waktu yang lama di tempat yang memiliki perbedaan budaya, membutuhkan penyesuaian dengan lingkungan budaya dimana ia akan berinterkasi dengan budaya yang berlainan. Orang yang berlainan budaya, tertutama budaya pendatang dalam hal in adalah pencari suaka sebagai budaya yang minoritass harus mampu beradaptasi agar mereka dapat mempertahankan kehidupan dan dapat berkembang dengan baik di tempat yang memiliki budaya yang mayoritas. Pencari suaka sebagai pendatang di Kota Pekanbaru haruslah melakukan adaptasi dengan masyarakat Kota Pekanbaru, baik melalui bahasa, perilaku, makanan, waktu, kebiasaan dan cara berpakaian serta tradisi yang ada di masyarakat Kota Pekanbaru.

Untuk memenuhi kebutuhan hidupnya selama berada di negara transit, pencari suaka dalam kesehariannya tidak akan terlepas dari proses interaksi, sosialisasi serta berkomunikasi dengan manusia lainnya. Disamping menjalankan aktifitas di lingkungan institusi formal, mereka melakukan interaksi sosial dengan sekelompok budaya lain yang beragam untuk dapat berkomunikasi. Teori interaksi simbolik didasarkan pada ide-ide 
mengenai diri dan hubungannya dengan masyarakat. Orang tergerak untuk bertindak berdasarkan makna yang diberikannya pada orang, benda, dan peristiwa. Makna-makna ini diciptakan dalam bahasa, yang digunakan orang baik untuk berkomunikasi dengan orang lain maupun dengan dirinya sendiri, atau pikiran pribadinya. Bahasa memungkinkan orang untuk mengembangkan perasaan mengenai diri dan untuk berinteraksi dengan orang lainnya dalam sebuah komunitas (West \& Turner, 2010). Sehingga, interaksi simbolik berasumsi bahwa manusia dapat mengerti berbagai hal dengan belajar dari pengalaman. Persepsi seseorang selalu diterjemahkan dalam simbolsimbol. Sebuah makna dipelajari melalui interaksi di antara orang-orang, makna tersebut muncul karena adanya pertukaran simbol-simbol dalam kelompok sosial(Kuswarno, 2013). Dalam penelitian ini, kajian dalam teori interaksi simbolik digunakan untuk membingkai, mengarahkan dan mengkonfirmasi penulis dalam menghimpun data-data tentang simbol-simbol dan makna dalam komunikasi yang dilakukan oleh pencari suaka dalam berinteraksi dengan masyarakat Kota Pekanbaru. Kemudian peneliti berusaha mengkontruksikan makna-makna simbol sehingga tergambar konsep-konsep dan kategori-kategori dari para pencari suaka.

Dalam penelitian ini, Teori Akomodasi Komunikasi juga digunakan untuk membedah permasalahan Komunikasi Adaptasi Lintas Budaya Pecari Suaka di Kota Pekanbaru ini. Akomodasi (Accomodation) didefinisikan sebagai kemampuan seseorang untuk menyesuaikan, memodifikasi dan mengatur perilaku seseorang dalam responnya terhadap orang lain. Akomodasi biasanya dilakukan secara tidak sadar.Dalam sebuah proses komunikasi dan interaksi dalam level interpersonal, terkadang terdapat perbedaan berdasarkan kelompok atau budaya, seperti perbedaan yang muncul pada kelompok usia, dalam aksen dan etnis, atau dalam kecepatan bicara (West \& Turner, 2010). Teori Akomodasi berkaitan dengan pemahaman mengenai interaksi serta adaptasi antarmanusia dari kelompok yang berbeda, dengan menilai bahasa perilakunon-verbal, dan paralanguage yang digunakan setiap individu. Teori Akomodasi juga menggabungkan pengaruh individualism dan kolektivism pada proses adaptasi. Teori akomodasi komunikasi, yang berpijak pada premis bahwa ketika sedang berinteraksi, mereka melakukan penyesuaian pembicaraan, pola vokal, atau tindaktanduk mereka untuk mengakomodasi orang lain (West \& Turner, 2010).

Berdasarkan fenomena diatas, penulis tertarik untuk melalukan penelitian tentang komunikasi adaptasi lintas pencari suaka dalam berinteraksi dengan masyarakat Kota Pekanbaru. Adapun tujuan dari penelitian ini adalah untuk megetahui bagaimana proses Komunikasi Adaptasi Lintas budaya yang dilakukan oleh pencari suaka dalam berinteraksi dengan masyarakat Kota Pekanbaru. 


\section{METODOLOGI PENELITIAN}

Penelitian tentang Komunikasi Adaptasi Lintas budaya yang dilakukan oleh pencari suaka dalam berinteraksi dengan masyarakat Kota Pekanbaru yang peneliti lakukan ini menggunakan paradigm Interpretif/ Konstruktivis karena peneliti ingin melihat dari sudut pandangan pencari suaka sebagai subjek yang diteliti tentang bagaimana proses adaptasi lintas budaya yang dilakukan oleh pencari suaka dengan masyarakat Kota Pekanbaru. Penelitian tentang Komunikasi Adpatasi Lintas Budaya Pencari Suaka dalam Berinteraksi dengan Masyarakat Kota Pekanbaru menggunakan metode kualitatif dengan pendekatan Fenomenologi. Peneliti berpikir metode ini sangat tepat menjadi cara yang dapat menguraikan permasalahan pada penelitian Komunikasi Lintas Budaya Pencari Suaka dengan Masyarakat Kota Pekanbaru. Titchen dan Hobson dalam (Barnawi \& Darojat, 2018) menjelesakan fenomenologi sebagai studi tentang kehidupan manusia sehari-sehari dalam konteks social tempat fenomena tersebut terjadi berdsarkan perspektif orang-orang yang terlibat langsung dalam pengalaman tersebut. Fenomena dapat secara langsung diteliti melalui eksplorasi pengetahuan manusia melalui akses kesadarannya, dan secara tidak langsung dengan melakukan investigasi terhadapt individu yang terlibat langsung melalui akses pandangan-pandangan dan pengalaman serta kesamaan latar belakang makna-makna. (Barnawi \& Darojat, 2018).

Penelitian Fenomenolohgi memiliki tujuan untuk mengetahui dunia dari sudut pandang seseorang yang mengalami kejadian secara langsung dan berkaita dengan sifat-sifat dasar alamiah manusia serta makna yang diberikan kepadanya. Dalam penelitian ini, penulis ingin menggali tentang proses komunikasi adaptasi lintas budaya, dalam berinteraksi dengan masyarakat Kota Pekanbaru. Informan dalam penelitian ini dipilih melalui teknik purposive yakni para pencari suaka yang berada di rumah detensi imigrasi Kota Pekanbaru yang sudah menetap di selama satu tahun atau lebih serta telah bias berbahasa Indonesia baik secara aktif maupun pasif. Penulis melakukan wawncara mendalam terhadap 11 orang pencari suaka dari berbagai negara yang menghubi Rudenim Kota Pekanbaru. 11 orang tersebut sudah memenuhi kriteria yang telah penulis jelaskan diatas. Selain itu juga, penulis juga melakukan wawancara kepada pimpinan dan petugas Rudenim serta kepada masyarakat sekitar dimana para pencari suaka tersebut beaktivitas dan berinteraksi satu sama lainnya. Teknik pengumpulan data menggunakan wawancara (indepth interviews), observasi, dokumentasi dan studi pustaka.

\section{HASIL DAN PEMBAHASAN}

\section{Adaptasi Pencari Suaka}

Adaptasi merupakan kemampuan, ketrampilan individu dan kelompok sosial dalam menghadapi lingkungan serta menghadapi perubahan-perubahan yang terjadi di dalam lingkungan hidupnya (Bennet, 2005). Banyak cara manusia untuk beradaptasi dengan lingkungan barunya. Salah satunya dengan mengikuti alur dan suasana di lingkungan 
baru itu. Ada kalanya manusia merubah kepribadian aslinya untuk menyesuaikan diri dengan lingkungan itu. Adaptasi diri yang dilakukan melalui mekanisme penyesuaian diri tergantung dari individu yang bersangkutan, dimana individu dapat mengubah diri sesuai dengan keadaan lingkungan, tetapi dapat juga individu mengubah lingkungan sesuai dengan keadaan dan keinginan dirinya sendiri. Jadi adaptasi sangat bergantung pada individu dalam melihat hambatan dan kesulitan yang dialami ketika melakukan interaksi dengan lingkungan barunya.

Adaptasi dalam konteks komunikasi lintas budaya berkaitan erat dengan adapatasi budaya dan adaptasi sosial. Orang-orang asing yang akan menetap dalam jangka waktu yang lama di tempat yang memiliki perbedaan budaya, membutuhkan penyesuaian dengan lingkungan budaya dimana ia akan berinterkasi dengan budaya yang berlainan. Orang yang berlainan budaya , tertutama budaya pendatang dalam hal in adalah pencari suaka sebagai budaya yang minoritass harus mampu beradaptasi agar mereka dapat mempertahankan kehidupan dan dapat berkembang dengan baik di tempat yang memiliki budaya yang mayoritas. Pencari suaka sebagai pendatang di Kota Pekanbaru haruslah melakukan adaptasi dengan masyarakat Kota Pekanbaru, baik melalui bahasa, perilaku, makanan, waktu, kebiasaan dan cara berpakaian serta tradisi yang ada di masyarakat Kota Pekanbaru.

Pencari suaka yang berada di Kota Pekanbaru menurut pengakuannya tidak terlalu sulit dalam melakukan adaptasi secara lintas budaya. Menurut mereka, hal ini dikarenakan terdapatnya kesamaan budaya yang ada di negara asal mereka dengan budaya yang ada di Kota Pekanbaru. Akan tetapi yang menjadi kendala utama adalah dalam penggunaan bahasa. Banyak para pencari suaka tidak bisa menggunakan Bahasa Indonesia ataupun Bahasa Inggris secara aktif, dan banyak pula masyarakat Kota Pekanbaru yang tidak bisa menggunakan Bahasa Inggris secara aktif pula. Hal ini menyebabkan para pencari suaka dan masyarakat berinteraksi dengan banyak menggunakan bahasa secara nonverbal. Berikut pernyataan dari GSR dalam kutipan wawancara:

"Ketika melakukan interaksi dengan masyarakat, banyak para deteni yang tidak paham menggunakan bahasa Indonesia ataupun Bahasa Inggris. Kalau saya sangat fasih dalam berbahasa Inggris, hal tersebut membuat saya dengan gampang berinteraksi dengan Pihak rudenim dan masyarakat, akan tetapi tidak dengan para deteni lainnya. Begitupula halnya dengan masyarakat Pekanbaru yang tidak semuanya pula paham berbahasa Inggris. Saya rasa inilah yang menjadi faktor utama kendala dalama berinterkasi dengan masyarakat, sehingga kita banyak mengandalakan komunikasi secara nonverval saja." (Wawancara dengan GSR, Pencari Suaka Asal Afganisthan)

Adaptasi dalam diri individu cenderung memiliki perbedaan antar satu sama lainnya. Perbedaan tersebut dapat disebabkan oleh berbagai macam faktor, misalnya faktor internal dari dalam diri (in self), dan faktor eksternal dari luar diri (out self) seperti penerimaan dari significant other di lingkungan masyarakat sekitarnya. Komunikasi eksternal sudah pasti akan dilakukan oleh pencari suaka. Hal tersebut merupakan 
dampak dari peraturan yang memperbolehkan pencari suaka untuk keluar dari rudenim dan membuat potensi yang sangat besar untuk berinterkasi dengan masyarakat.

Komunikasi eksternal yang dilakukan oleh pencari suaka dipengaruhi oleh budaya, norma dan nilai masyarakat lokal akan tetapi tidak juga meninggalkan identitas budaya asal mereka. Dalam praktekanya, tidak semua juga yang memanfaat waktu untuk keluar dari rudenim yang diberikan oleh pihak rudenim tersebut, artinya tidak semua pencari suaka mau membuka diri dan berinterkasi dengan masyarakat kota Pekanbaru. Hal tersebut disebabkan karena faktor keterbatasan dalam berbahasa seperti yang telah dijelaskan diatas. Pencari suaka yang sama sekali tidak bisa Berbahasa Indonesia ataupun Berbahasa Inggris cenderung lebih tertutup dan tidak pernah melakukan interaksi dengan masyarakat Kota Pekanbaru. Penulis mempunyai informan yakni pencari suaka asal Bangladesh yang sama sekali tidak bisa berbahasa Indonesia ataupun berbahasa Inggris.

\section{Adaptasi Komunikasi Verbal dan Nonverbal}

Konvergensi merupakan strategi yang dilakukan untuk melakukan akomodasi komunikasi lintas budaya yang dilakukan pencari suaka dalam beradaptasi. Perbedaan budaya antar pencari suaka dengan kebudayaan masyarakat setempat sudah pasti memiliki perbedaan dalam berbahasa. Pencari Suaka kebanyakan menggunakan bahasa Parsi, yang mana bahasa Parsi ini adalah bahasa nasional dari negara-negara pencari suaka berasal. Bahasa Indonesia dan Bahasa Parsi sudah pasti memiliki perbedaan yang sangat signifikan sehingga menuntut mereka untuk belajar berkomunikasi dengan menggunakan Bahasa Indonesia atau Bahasa Inggris sebagai bahasa Pengantar Internasional.

Berdasarkan hasil pengamatan yang penulis lakukan, pencari suaka yang telah menetap di Pekanbaru lebih dari satu tahun, biasanya akan mudah untuk berkomunikasi dengan masyarakat Kota Pekanbaru. Mereka yang telah menetap lebih dari satu tahun sudah bisa berbahasa Indonesia, meskipun dengan berbagai macam tingkatan. Ada yang sudah lancar dan ada juga yang masih terbata-bata. Selain itu juga, para pencari suaka tersebut juga sudah memahami lingkungan di Kota Pekanbaru. Informan peneliti berinisial NA mengaku dia sudah sangat fasih sekali menggunakan bahasa Indonesia, bahkan NA juga sudah mengerti beberapa kosa kata dalam berbahasa daerah. Berikut Kutipan wawancara penulis dengan NA:

"Awal saya berada disini saya tidak bisa sama sekali berbahasa Indonesia. Saya belajar dari teman-teman disini. Sekarang saya sudah bisa berbahasa Indonesia bahkan saya bisa bahasa minang "Saketek-saketek". Saya sudah lebih dari dua tahun berada disini, dan saya banyak sekali memiliki teman orang Pekanbaru. Dari teman saya itulah saya bisa berbahasa Minang". (Wawancara dengan NA, Pencari Suaka asal Afganisthan)

Komunikasi nonverbal memainkan peranan yang sangat penting dalam kehidupan kita ketika kita berkomunikasi dengan orang-orang yang kita temui. Komunikasi nonverbal 
adalah sebuah proses menggunakan pesan-pesan tanpa kata untuk menyamakan makna. Bahasa nonverbal merupakan salah satu bentuk komunikasi yang sering digunakan dalam presentasi, dimana penyampaiannya bukan dengan kata-kata ataupun suara tetapi melalui gerakan-gerakan anggota tubuh yang sering dikenal dengan istilah bahasa isyarat atau body language. Selain itu juga, penggunaan bahasa nonverbal dapat melalui kontak mata, penggunaan objek seperti pakaian, potongan rambut, dan penggunaan simbolsimbol.

Komunikasi nonverbal mayoritas yang digunakan adalah kinesics yang dipresentasikan melalui gerakan-gerakan badan. Pengamatan yang penulis lakukan di Rudenim Kota Pekanbaru, ketika para pencari suaka berinterkasi dengan petugas ataupun dengan masyarakat ketika ingin membeli keperluan sehari-hari di minimarket, kebanyakan para pencari suaka menggunakan gerakan "Ala Tarzan" untuk mengkomunikasi yang dimaksud kepada lawan bicaranya. Begitu juga dengan petugas rudenim, ketika memberi sebuah pesan kepada pencari suaka dalam bahasa Inggris, ada beberapa pencari suaka yang tidak paham dan akhirnya menggunakan bahasa dengan gerakan tubuh. Informan peneliti Mn yang sama sekali tidak bisa menggunakan Bahasa Indonesia ataupun Bahasa Inggris, ketika berinteraksi dengan masyarakat selalu menggunakan komunikasi nonverbal dengan gerakan tubuh. Seperti pernyataan Mn sebagai berikut:

"Kalau mau beli sesuatu di toko saya cuma tinggal tunjuk saja dan penjual akan paham apa yang mau saya beli. Begitu juga ketika berpapasan dengan masyarakat, mereka tersenyum dan saya juga tersenyum." (Wawancara dengan Mn, Pencari Suaka Asal Afganisthan)

Bagi Mn yang sama sekali tidak bisa menggunakan komunikasi secara verbal akibat keterbatasan bahasa, membuat ia hanya mengandalkan komunikasi nonverbal ketika dia tengah membeli keperluan di toko. Dan seperti pernyataannya juga, bahwa ia selalu melontarkan senyum kepada warga yang menyapanya, ataupun sekedar melambaikan tangan kepada masyarakat yang menegurnya.

Hambatan utama dalam komunikasi antarbudaya yang dirasakan pencari suaka dan masyarakat pribumi adalah bahasa. Walaupun ada beberapa orang dari pencari suaka yang sudah bisa menggunakan bahasa Indonesia, namun mayoritas mereka tidak bisa berbahasa Indonesia. Ketidaksamaan bahasa yang dimiliki oleh Indonesia dan bahasa asli Negara para pencari suaka membuat jarang berkomunikasi dengan masyarakat Pekanbaru. Pencari suaka berusaha keras untuk melakukan berbagai cara agar data bisa berkomunikasi dan beradaptasi serta berinteraksi dengan masyarakat. Salah satu cara yang dilakukan oleh pencari suaka adalah dengan memanfaatkan google translate. Upaya ini dilakukannya untuk dapat mengimbangi bahasa yang digunakan oleh kaum pribumi. Seperti yang disampiakan bapak Iwan selaku kepala Rudenim Kota Pekanbaru dan Rully Fatria selaku Staf Bagian Keaman Rudenim Pekanbaru: 
"Pencari suaka yang telah menetap di Pekanbaru tak kurang dari 2 tahun pada umumnya mereka telah paham akan kondisi dan bahasa di pekanabru. Ada bberapa dari mereka yang sudah fasih berbahasa Indonesia, bahkan ada dari mereka yang sudah fasih juga berbahasa minang. Tapi kebanyakan masih hanya sekedar saja, artinya bahasa Indonesia yang dipergunakan sehari-hari." (Wawancara dengan Rulli Fatria, Petugas Rudenim Pekanbaru)

Bahasa Inggris sebagai bahasa pengantar Internasional memiliki peranan penting bagi pencari suaka untuk melakukan adaptasi dengan lingkungan sekitar. Kemampuan para pencari suaka untuk menggunakan bahasa Inggris sebagai salah satu bentuk adaptasi lintas budaya ternyata juga didukung dengan kegiatan kursus Bahasa Inggris dan juga Bahasa Indonesia yang diberikan oleh Rudenim.

\section{Adaptasi Berdasarkan Kesamaan Agama}

Islam merupakan agama yang mayoritas di Kota Pekanbaru. Begitu pula halnya dengan para pencari suaka yang berasal dari negara-negara Islam Timur Tengah yang bermayoratis memeluk agama Islam. Kesamaan sama-sama memeluk agama Islam, menjadikan para pencari suaka mudah dalam berinteraksi dan beradaptasi dengan masyarakat Kota Pekanbaru. Oleh karena itu, salah satu cara yang pencari suaka dalam beradaptasi adalah dengan asas persamaan sama-sama beragaman Islam.

Faktor kesamaan agama membuat para pencari suaka tidak mengalami kesulitan untuk beradaptasi dengan lingkungan dan masyarakat kota Pekanbaru. Pencari suaka tidak merasakan kesulitan untuk menerima nilai-nilai yang dianut masyarakat Pekanbaru, karena sama dengan negara mereka. Hal ini justru akan lebih mempermudah bagi para pencari dalam beradaptasi, akbiat adanya kesamaan dalam kepercayaan tersebut. Mungkin akan berbeda ketika para pencari suaka berada di negara yang bukan mayoritas memeluk agama yang sama dengannya.

Informan peneliti bernama Sh mengakui kesamaan agama Islam antara para pencar suaka dengan masyarakat Pekanbaru membuatnya tidak terlalu sulit untuk beradaptasi. Sh sendiri dengan leluasa dan santai bebas melakukan ibadah tanpa canggung dengan perbedaan. Berikut kutipan wawancara peneliti dengan Sh:

“...Masyarakat disini mayoritas beragama Islam, sama dengan Negara Saya. Saya bebas beribadah disini. Saya bebas ke masjid untuk sholat lima waktu, Sholat Jumat ataupun hanya sekedar untuk sholat Sunnat saja. Mesjid juga tidak sulit untuk dicari disni. Jadi saya masih merasakan seperti berada di Negara sendiri." (Wawancara dengan Sh, Pencari Suaka asal Afganisthan)

Kebebasan yang didapatkan oleh Sh dalam melaksanakan ibdaha sesuai dengan keyakinan membuat Sh lebih mudah untuk beradaptasi dengan Masyarakat Kota Pekanbaru. Sh yang beragama Islam, sama dengan penduduk Pekanbaru yang mayoritas memeluk agama Islam. Pernyataan Sh diatas menggambarkan bahwa akibat kesamaan agama ini, membuat dirinya tidak terlalu mengalami kesulitan dalam beradaptasi, 
bahkan bagi Sh dia merasa berada di Negaranya sendiri. Karena berbaur di lingkungan yang seiman membuat dia tidak canggung berada ditengah-tengah masyarakat. tidak ada yang melarang atau menganggu jika ia ingin melaksanakan ibadah, baik di rudenim ataupun di masjid. Selain itu juga, karena banyaknya masjid yang ada di Pekanbaru membuat Sh merasa senang.

\section{Adaptasi Cara Berpakaian}

Adaptasi merupakan suatu proses perubahan yang menyertai individual dalam berespon terhadap perubahan yang ada di lingkungan dan dapat mempengaruhi keutuhan tubuh, baik secara fisiologis maupun secara psikologis ini dapat berupa semua respon dengan berusaha mempertahankan keseimbangan dari suatu keadaan. Selain itu respon adaptif juga merupakan suatu totalitas respon dari manusia sebagai makhluk holistik yang memerlukan waktu dalam proses penyesuian (Murwani,2009). Adaptasi merupakan proses dan hasil dimana berpikir dan merasa orang, sebagai individu atau dalam kelompok, yang menggunakan kesadaran dan pilihan untuk membuatintegrasi manusia dan lingkungan (Callista Roy,1999).

Bagi pencari suaka, salah satu cara yang mereka lakukan dalam beradaptasi dengan Masyarakat Pekanbaru adalah dengan cara berpakaian. Cara berpakaian merupakan salah satu bentuk komunikasi yang dilakukan secara nonverbal. Bagaimana kita berpakaian, akan menggambarkan bagaimanapula kepribadian diri kita. Orang pertama sekali akan menilai diri kita dari pakaian yang kita gunakan. Oleh karena itu, pakaian pada dasarnya adalah bentuk penyampaian pesan yang dapat mengkomunikasikan banyak makna kepada komunikan.

Dalam beradaptasi dengan masyarakat Kota Pekanbaru, pencari suaka juga mengikuti cara berpakaian seperti masyarakat Pekanbaru. Berdasarkan pengamatan yang peneliti lakukan, pencari suaka merubah gaya berpakaian mereka menjadi seperi gaya berpakaian masyarakat kota Pekanbaru. Pencari suaka sudah menggunakan baju kaos atau kemeja, celana jeans atau celana pendek. Cara berpakaian seperti itu jelaslah berbeda dengan cara berpakaian dari Negara mereka berasal, dimana di Negara asal mereka dalam kesehariannya mereka menggunakan pakaian Gamis. Dalam wawancara yang penulis lakukan dengan NA mengatakan sebagai berikut:

"Saya disini sudah memakai baju kaos, celana jeans ataupun celana pendek. Banyak teman saya disini yang mengajarkan cara berpakaian dan style lainnya, agara saya sama seperti masyarakat. Saya tidak pernah lagi memakai gamis, sesekali ketika Sholat ke masjid saya masi memakai Gamis." (Wawancara dengan NA, Pencari Suaka asal Afganisthan)

NA telah beradaptasi dengan cara mengikuti style dan cara berpakaian sama seperti masyarakat Pekanbaru. Hal tersebut sangat berbeda jauh sekali dengan cara berpakaian di Negaranya, dimana sehai-hari di Negaranya NA mengenakan pakaian gamis. Akan tetapi selama berada di Pekanbaru, NA tidak lagi menggunakan gamis. Baju Gamis hanya 
digunakan sesekali oleh NA saat akan pergi melaksanakan Sholat ke masjid. NA juga menyatakan bahwa, temannya juga telah membantu dalam pemilihan serta cara berpakaian NA.

\section{Adaptasi Dengan Iklim}

Keadaan rata-rata suatu cuaca di dalam suatu daerah dalam kurun waktu yang cukup lama minimal berkisar 30 tahun yang bersifat tetap merupakan pengertian dari iklim menurut ahli. Berbeda Negara, berbeda pula iklimnya. Iklim dibagi menjadi empat yakni Tropis, Subtropis, Sedang dan Dingin. Iklim Tropis biasa ditemukan di daerah sekitar garis ekuator Bumi, di antara garis 23,5 derajat Lintang Utara sampai 23,5 derajat Lintang Selatan. Indonesia sendiri seperti yang kita ketahui memiliki Iklim Tropis. Hal ini dikarenakan posisi Indonesia yang terletak pada garis khatulistiwa. Hal tersebut membuat iklim yang ada di Indonesia berbeda dengan Iklim yang ada dari negara-negara asal para pencari suaka.

Bagi para pencari suaka yang berasal dari negara-negara di Afganistan, Pakistan, Irak, Iran dan beberapa negara timur tengah lainnya memiliki 4 musim, yakni musim dingin, musim panas, musim semi, dan musim gugur. Berbeda dengan Indonesia yang hanya memiliki dua musim yakni musim panas dan musim dingin. Perbedaan musim itu membuat para pencari suaka harus beradaptasi dengan kondisi iklim dan cuaca yang ada di Pekanbaru.

Adaptasi terhadap lingkungan alam yang dilakukan oleh pencari suaka yang berada di Rudenim Kota Pekanbaru awalnya mengalami kesulitan. Hal ini disebabkan oleh perbedaan cuaca yang terjadi antara negara mereka dan Indonesia, khususnya cuaca kota Pekanbaru yang beriklim panas. Para pencari suaka harus mampu beradaptasi dengan kondisi cuaca yang terjadi di Kota Pekanbaru. Perbedaan cuaca antara negara asal mereka yang memiliki kondisi cuaca yang dingin sedangkan di Kota Pekanbaru bercuaca panas. Hal itu membuat mereka harus mampu beradaptasi dengan cuaca yang ada.

"Aku rasa beberapa dari mereka akan mau, beberapa tidak suka tinggal disini karena mereka mengeluh tentang cuacanya. Biasanya di Afganistan, tempat kelahiranku memiliki 4 musim. Musim dingin, semi, sangat sulit untuk tinggal di tempat yang hanya ada panas dan dingin." (Wawancara dengan GSR, Pencari Suaka asal Afganisthan)

Berdasarkan hasil wawancara yang dilakukan dengan GSR salah seorang pencari suaka mengatakan bahwa adapatasi secara lingkungan alam yang harus mereka lakukan adalah berdapatasi dengan kondisi iklim yang berada di Indonesia khususnya Kota Pekanbaru. GSR mengatakan di negara mereka yang memiliki Empat musim yakni Dingin, Panas, Gugur dan Semi membuat mereka harus mampun beradaptasi secara lingkungan alam dengan Indonesia khususnya Pekanbaru yang hanya memiliki dua Musim, yakni panas dan dingin. 
Menurut Eko A. Meinarno dkk, adaptasi adalah proses penyesuaian diri terhadap lingkungan dan keadaan sekitar (Eko A. Meinarno dkk, 2011: 66). Di dalam Kamus Besar Bahasa Indonesia, adaptasi sosial berarti proses perubahan dan akibatnya pada seseorang dalam suatu kelompok sosial sehingga orang itu dapat hidup atau berfungsi lebih baik dalam lingkungannya. Dari pengertian di atas dapat disimpulkan bahwa adaptasi adalah proses penyesuaian diri terhadap lingkungan sekitar yang bertujuan untuk mendapatkan kehidupan yang lebih baik dalam lingkungannya.

Komunikasi lintas budaya yang terjadi antara pencari suaka dengan masyarakat Kota Pekanbaru terjadi di dalam konteks sosial yang membutuhkan interaksi satu sama lainnya. Sebagai masyarakat yang minortas dan pendatang di Kota Pekanbaru, para pencari suaka akan melakukan proses adapatasi dalam segala hal agar mereka dapat lebih nyaman dan betah serta bisa diterima di tengah-tengah masyarakat Kota Pekanbaru. Para pencari suaka adalah sama seperti manusia lazimnya yang merupakan makhluk sosial. Makhluk sosial adalah makhluk yang tidak bisa hidup tanpa orang lain. Oleh karena itu, para pencari suaka dalam melakukan berinteraksi dengan masyarakat Kota Pekanbaru perlu melakukan proses adaptasi agar dapat mempertahankan kehidupan mereka selama berada di Rudenim Kota Pekanbaru sampai akhirnya diberangkatkan ke Negara ketiga yang menjadi tujuan akhir mereka.

Gudykunst \& Mody (2003) menyatakan bahwa motivasi setiap orang untuk beradaptasi berbeda-beda. Kemampuan individu untuk berkomunikasi sesuai dengan norma-norma dan nilai-nilai budaya yang baru tergantung pada proses penyesuaian diri atau adaptasi mereka. Walaupun demikian, setiap orang harus menghadapi tantangan beradaptasi agar dapat bermanfaat bagi lingkungan barunya. Lebih lanjut Gudykunts dan Kim (2003) menegaskan bahwa setiap individu harus menjalani proses adaptasi di kala bertemu ataupun berinteraksi dengan lingkungan dan budaya yang berbeda dengannya. Menurut Kim, proses adaptasi antar budaya merupakan proses interaktif yang berkembang melalui kegiatan komunikasi individu pendatang dengan lingkungan sosial budayanya yang baru.

Ada dua tahapan dalam proses adaptasi yang dikemukakan oleh Kim, yakni cultural adaptation dan cross cultural adaptation. Cultural adaptation adalah proses dasar komunikasi dimana terdapat proses penyampaian pesan media, serta adanya penerima pesan, sehinggan dalam proses tersebut terjadi yang namanya encoding dan decoding. Proses tersebut diartikan sebagai tingkat perubahan yang terjadi ketika seseorang berada daam lingkungan yang baru. Dalam prosesnya akan terjadi pengiriman pesan oleh masyarakat setempat di lingkungan baru tersebut yang akan dapat dipahami oleh individu pendatang. Hal tersebut dikenal dengan instilah Enculturasi, dimana proses enculturasi akan terjadi pada saat sosialisasi.

Proses selanjutnya adalah Cross Culture Adaptation. Dalam prses ini terdapat tiga hal utama yakni acculturation, deculturation, dan assimilation. Aculturation terjadi ketika 
pendatang baru melalui proses sosialisasi dan mulai melakukan interaksi dengan budaya baru yang terdapat dilingkungan barunya tersebut. Seiring berjalannya waktu, pendatang akan memahami budaya setempat dan memilih norma serta nilai budaya local yang dianutnya. Walaupun demikian, pola budaya terdahulu juga akan mempengaruhi dalam proses adaptasi tersebut. Hal tersebut dinamakan denan deculturation. Deculturation merupakan hal kedua dari prses adaptasi dimana pola budaya terdahulu akan mempengaruhi dalam proses adaptasi. Perubahan akulturasi akan mempengaruhi psikologis dan perilaku sosial para pendatang dengan identitas baru, norma dan nilai baru sehingga memugkinkan pendatang akan mengisolasi diri dari penduduk local setempat. Tahapan terakhir adalah proses assimilation yaitu keadaan dimana pendatang meminimalisir penggunaan budaya lama sehigga akan terlihat seperti masyarakat setempat pada umumnya. (Gudykunst \& Mody, 2003)

Peneliti juga mengkonfirmasi hasil temuan lapangan dengan Teori Akomodasi Komunikasi. Akomodasi komunikasi yang dilakukan pencari suaka di Rudenim Kota Pekanbaru ketika berinterkasi dengan masyarakat Kota Pekanbaru. Kecendrungan akomodasi terlihat dari tiga elemen yang mereka lakukan dalam berkomunikasi dengan masyarakat, yakni melalu bahasa paralanguage dan perilaku nonverbal. Bahasa menjadi elemen yang paling menonjol menunjukkan adanya akomodasi komunikasi. Hal ini dikarenakan bahasa para pencari suaka berbeda dengan bahasa masyarakat Kota Pekanbaru, mengingat mereka berasal dari latar belakang budaya dan geografis yang berbeda pula.

Selanjutnya penulis juga mengkonfirmasi hasil temua tentang Komunikasi Adaptasi Lintas Budaya ini dengan Teori Akomodasi Komunikasi dari Giles. Penulis mengkonfirmasi temua di lapangan dengan menggunakan teori akomodasi komunikasi ini dikarenakan Akomodasi komunikasi adalah sebuah proses dimana ia tidak muncul begitu saja. Akomodasi komunikasi dipengaruhi oleh banyak faktor seperti motivasi dan power. Akomodasi didefinisikan sebagai kemampuan untuk menyesuaikan, memodifikasi, atau mengatur perilaku seseorang dalam responnya terhadap orang lain (West \& Turner, 2010)

Hasil penelitian menunjukan kecendrungan akomodasi komunikasi yang dilakukan pencari suaka di Rudenim Kota Pekanbaru ketika berinterkasi dengan masyarakat Kota Pekanbaru. Kecendrungan akomodasi terlihat dari tiga elemen yang mereka lakukan dalam berkomunikasi dengan masyarakat, yakni melalu bahasa paralanguage dan perilaku nonverbal. Bahasa menjadi elemen yang paling menonjol menunjukkan adanya akomodasi komunikasi. Hal ini dikarenakan bahasa para pencari suaka berbeda dengan bahasa masyarakat Kota Pekanbaru, mengingat mereka berasal dari latar belakang budaya dan geografis yang berbeda pula.

Akomodasi sangat dipengaruhi oleh beberapa keadaan personal, situasional, dan budaya (Yasir, 2011, p. 202). Modifikasi sebagai bentuk akomodasi atau adaptasi untuk mencapai 
komunikasi yang efisien biasanya disebut dengan konvergensi. Sedangkan akomodasi yang cenderung mempertegas perbedaan ini sering disebut dengan divergensi. Berdasarkan hasil penelitian, peneliti menemukan akomodasi komunikasi baik akomodasi konvergensi maupun divergensi yang dilakukan oleh pencari suaka dalam interaksi lintas budaya untuk komunikasi yang efektif dengan masyarakat kota Pekanbaru dipengaruhi oleh beberapa keadaan personal, situasional, dan budaya.

Strategi konvergensi merupakan sebuah strategi individu dalam beradaptasi dalam berkomunikasi satu sama lain. Dalam strategi konvergensi orang akan beradaptasi dengan kecepatan bicara, bahasa, jeda bicara, senyuman, tatapan mata, perilaku verbal maupun perilaku nonverbal (West \& Turner, 2010). Peneliti menemukan tentanng strategi konvergensi yang dilakukan oleh pencari suaka ketika melakukan interaksi antar budaya dengan masyarakat kota pekanbaru berupa pengaturan penggunaan bahasa indonesia dan bahasa Inggris, penggunaan isyarat tangan untuk menegaskan apa yang mereka maksudkan ketika tidak tercapai kesamaan makna dalam pengunaan bahasa lisan dengan masyarakat penyesuaian penggunaan pakaian seperti masyarakat pribumi kota Pekanbaru dimana di negara asalnya pencari suaka menggunakan jubah dalam kesehariannya, dan penyesuaian dengan nilai-nilai norma agama Islam masyarakat Kota Pekanbaru dimana mereka juga berasal dari negara Islam. Uraian tersebut sesuai dengan apa yang dikonsepkan oleh (West \& Turner, 2010), bahwa strategi konvergensi merupakan strategi yang digunakan oleh komunikator untuk beradaptasi dengan segala bentuk komunikasi verbal dan nonverbal yang dimiliki oleh lawan bicaranya.

Strategi divergensi adalah strategi dimana tidak adanya usaha-usaha untuk menunjukkan kesamaan antara kedua komunikator seperti dalam hal kecepatan bicara, tindak tanduk, segala bentuk komunikasi verbal dan nonverbal dalam percakapan (West \& Turner, 2010). Jika pada strategi konvergensi adalah cara untuk menciptakan kesamaan, maka strategi divergensi adalah kebalikannya. Pelaku-pelaku komunikasi pada strategi ini saat berdialog berusaha menonjolkan perbedaan-perbedaan budaya, perilaku, kebiasaan dan ketertarikannya.

Perilaku komunikasi verbal yang menandakan strategi divergensi pencari suaka adalah tidak adanya usaha untuk mengetahui dan menggunakan bahasa lawan bicaranya. Ini penulis temukan dari beberapa informan yang berkewarganegaraan Bangladesh. Informan peneliti dari Bangladesh ini tidak bisa sama sekali berbahasa Indoenesia ataupun berbahasa Inggris. Akibat rendahnya tingkat pendidikan, tidak ada usaha baginya untuk berusaha belajar dan berbicara dengan menggunakan bahasa Indoensia ataupun Bahasa Inggris. Maka ketika mereka ingin sesuatu mereka menggunakan temannya yang fasih berbahasa Ingris atau pun berbahasa Indonesia sebagai penterjemah apa yang mereka maksudkan saat berinteraksi dengan masyarakat Kota Pekanbaru. Disini saat dengan kelompoknya (ingroup) para pencari suaka tetap menonjolkan cara mereka berbahasa dengan menggunakan bahasa asal mereka. Dengan demikian, sesuai dengan penjelasan (West \& Turner, 2010), bahwa divergensi tidaklah 
bersifat negatif dan divergensi tidak sama dengan ketidakpedulian, ketika seseorang memutuskan untuk melakukan divergensi, maka mereka memutuskan untuk mendisosialisasikan diri mereka dari komunikator dan percakapan tersebut.

Setiap komunikasi yang terjadi antara pencari suaka dengan masyarakat kota Pekanbaru, penggunaan jarak juga merupakan bentuk strategi divergensi yang dilakukan. Hal tersebut dibuktikan dengan pencari suaka yang tidak menghiraukan jarak saat berkomunikasi dan tidak berusaha mengetahui kebutuhan jarak lawan bicaranya. Sementara, masyarakat kota Pekanbaru lebih menonjolkan jarak yang dibutuhkan untuk memperhatikan dan berusaha mengetahui apakah jarak tersebut membuat lawan bicara nyaman atau tidak. Hal tersebut dibuktikan bahwa pencari suaka tidak menghiraukan jarak saat berkomunikasi dan tidak berusaha mengetahui kebutuhan jarak lawan bicaranya dan berusaha mengetahui apakah jarak tersebut membuat nyaman lawan bicaranya disebabkan jarangnya mereka berinteraksi dengan masyarakat pribumi di luar berinteraksi hanya untuk memenuhi keperluannya saja.

\section{SIMPULAN}

Komunikasi adaptasi lintas budaya yang dilakukan oleh pencari suaka dilakukan melalui dua strategi, yakni stratgei konvergensi dan strategi divergensi. Strategi konvergensi yang dilakukan oleh pencari suaka ketika melakukan interaksi antar budaya dengan masyarakat kota pekanbaru berupa pengaturan penggunaan bahasa indonesia dan bahasa Inggris, penggunaan isyarat tangan untuk menegaskan apa yang mereka maksudkan ketika tidak tercapai kesamaan makna dalam pengunaan bahasa lisan dengan masyarakat penyesuaian penggunaan pakaian seperti masyarakat pribumi kota Pekanbaru dimana di negara asalnya pencari suaka menggunakan jubah dalam kesehariannya, dan penyesuaian dengan nilai-nilai norma agama Islam masyarakat Kota Pekanbaru dimana mereka juga berasal dari negara Islam. Perilaku komunikasi verbal yang menandakan strategi divergensi pencari suaka adalah tidak adanya usaha untuk mengetahui dan menggunakan bahasa lawan bicaranya. Setiap komunikasi yang terjadi antara pencari suaka dengan masyarakat kota Pekanbaru, penggunaan jarak juga merupakan bentuk strategi divergensi yang dilakukan. Hal tersebut dibuktikan dengan pencari suaka yang tidak menghiraukan jarak saat berkomunikasi dan tidak berusaha mengetahui kebutuhan jarak lawan bicaranya. Sementara, masyarakat kota Pekanbaru lebih menonjolkan jarak yang dibutuhkan untuk memperhatikan dan berusaha mengetahui apakah jarak tersebut membuat lawan bicara nyaman atau tidak. Hal tersebut dibuktikan bahwa pencari suaka tidak menghiraukan jarak saat berkomunikasi dan tidak berusaha mengetahui kebutuhan jarak lawan bicaranya dan berusaha mengetahui apakah jarak tersebut membuat nyaman lawan bicaranya disebabkan jarangnya mereka berinteraksi dengan masyarakat pribumi diluar beinteraksi hanya untuk memenuhi keperluannya saja. Komunikasi adaptasi lintas budaya yang dilakukan oleh pencari suaka antara lain beradaptasi dengan komunikasi verbal, adaptasi dengan 
komunikasi nonverbal, adaptasi dengan asas persamaan agama Islam, adaptasi dengan cara berpakaian, serta beradaptasi dengan iklim yang ada di Kota Pekanbaru.

\section{DAFTAR PUSTAKA}

Barnawi, \& Darojat, J. (2018). Penelitian fenomenologi Pendidikan. Ar-Ruzz Media.

Bennet, J.W. (2005). The Ecological Transition Cultural Anthropology And Human Adaptation. Washington University at St. Louis.

Gudykunst, W. B., \& Mody, B. (2003). Handbook of International and Cultural Communication. (2nd ed.). Sage Publications.

Kurniawati, R. N. K. (2016). Komunikasi Lintas Budaya Diaspora Indonesia di Jerman (Studi Fenomenologi Konstruksi Makna dan Komunikasi Adaptasi Diaspora Indonesia Bekerja di Jerman) (No. Publikasi 000172985) [Disertasi doktoral, Universitas Padjajaran]. Unpad Repository.

Kuswarno, E. (2013). Metode Penelitian Komunikasi, Fenomenologi, Konsepsi, Pedoman dan Contoh Penelitiannya. Widya Padjadjaran.

Littlejohn, S. W., \& Foss, K. A. (2009). Encyclopedia of Communication Theory. Sage Publication.

Lubis, L. A. (2012). Komunikasi Antarbudaya Etnis Tionghoa dan Pribumi di Kota Medan. Jurnal Ilmu Komunikasi, 10(1), 13-27. Diperoleh dari http://jurnal.upnyk.ac.id/index.php/komunikasi/article/view/83

Martin, J., Nakayama, N., \& K, T. (2012). Intercultural Communication In Contexts. McGrawHill Education.

McNevin, A., Missbach, A., \& Mulyana, D. (2016). The Rationalities of Migration Management: Control and Subversion in an Indonesia-Based Counter-Smuggling Campaign. International Political Sociology, 10(3), 223-240. https://doi.org/https://doi.org/10.1093/ips/olw009

West, R., \& Turner, L. H. (2010). Introducing Communication Theory: Analysis and Application (3rd ed.). Salemba Humanika.

Yusanto, Y. (2018). Komunikasi Lintas Budaya Orang Asli Papua Di Belanda (No. Publikasi 000034469) [Disertasi doktoral, Universitas Padjajaran]. Unpad Repository. 